\title{
TEKNOLOGI DALAM PEMBELAJARAN PENDIDIKAN AGAMA KRISTEN YANG ANTISIPATIF DI ERA REVOLUSI INDUSRI 4.0
}

\author{
Djoys Anneke Rantung ${ }^{1}$, Fredik Melkias Boiliu ${ }^{2}$ \\ djoys.anneke@gmail.com ${ }^{1}$, boiliufredik@gmail.com² \\ Universitas Kristen Indonesia ${ }^{1,2}$
}

\begin{abstract}
Abstrak
Artikel ini bertujuan untuk membahas tentang bagaimana manusia menciptakan, menggunakan dan mengembangkan teknologi sesuai iman Kristen.Teknologi sudah ada sejak saat manusia diciptakan. Manusia diciptakan menurut gambar dan rupa Allah (Imago Dei) Kejadian 1:27-28. Allah memerintahkan manusia untuk menciptakan bahtera dan Allah turut campur tangan menentukan dimensi ruang bahtera bahkan bahannya pun Allah yang menentukan. Keterlibatan Allah dalam menciptakan teknologi menunjukan bahwa teknologi diciptakan tujuannya digunakan untuk keselamatan manusia dan untuk kemuliaan Tuhan. Allah memperlengkapi manusia dengan akal budi sehingga lewat akal budi inilah manusia mengembangkan teknologi dengan cepat, sesuai perkembangan zaman dan peradaban. Manusia yang menciptakan teknologi seharusnya manusia pula yang mengusai teknologi namun faktanya teknologi yang menguasai manusia, manusia menjadi budak teknologi dan mentuhankan teknologi. Dalam penulisan ini, memasukan pendidikan agama Kristen sebagai upaya untuk mengantisipasi penggunaan teknologi menurut iman Kristen di era revolusi industri 4.0 melalui pengajaran pendidikan agama Kristen di lingkungan keluarga, gereja dan sekolah. Metode yang digunakan dalam penulisan ini adalah kajian literaur dan riset pustaka.
\end{abstract}

Kata kunci: Teknologi, Iman, Pendidikan Agama Kristen

\begin{abstract}
This Article aims to discuss about humans creating, using and developing technology according to the Christian Faith. Technology has existed since humans were created. humans are made in image and likeness of God (Imago Dei) Genesis 1:27-28. God ordered humans to create the ark, and He intervened to determine the demensions of the ark's space also all the materials. God's involvement in creating technology shows that technology was created to be used for human salvation and for God's glory. God equip humans with knowledge therefore humans can develop technology quickly in accordance with times and civilization. Humans who create technology should be able to master technology but in reality technology dominates humans. Humans become technology slaves and deife technology. In this paper we include Christian religious education as an effort to anticipate the use of technology according to the Christian Faith in the era of the industrial revolution 4.0 through the teaching of Christian religious education in the family environment, Church, and School. The methods used are literature study and library research
\end{abstract}




\section{Keywords: Technology, Faith, Christian Religious Education}

\section{Pendahuluan}

Manusia pada dasarnya yang menciptakan teknologi dan menggunakan untuk mempermudahnya melakukan aktivitas dalam kehidupan sehari-hari. Dalam hal ini, teknologi sudah ada sejak manusia di ciptakan. Allah menciptakan manusia menurut gambar dan rupa-Nya (Imago Dei) dan memperlengkapi manusia dengan kekuatan berpikir (rasio) (Kej. 1:27-31) ${ }^{1}$ dengan tujuan agar manusia berpikir dan mampu menggali potensi alam untuk memenuhi kebutuhannya. Allah memerintahkan manusia untuk menciptakan teknologi dan menggunakannya untuk menyelamatkan dirinya. Hal itu terlihat jelas dalam beberapa contoh tentang teknologi dalam Alkitab. Di dalam kitab Kejadian kisah air bah, Allah memerintahkan Nuh membuat kapal untuk menyelamatkan dirinya dan keluarganya dari kebinasaan air bah. Dalam hal ini, kemampuan Nuh bukan berarti Allah tidak campur tangan dalam menentukan pembangunan kapal tersebut tetapi Allah menentukan dimensi ruang dalam kapal bahkan bahannya pun Allah yang menentukan (Kej. 6:14-15). ${ }^{2}$ Dalam Kitab Keluaran juga Musa diperintahkan Allah untuk membuat kemah Suci (Kel. 25:9). Allah sendiri telah menjadi arsitek yang merencanakan ruang-ruang, dimensi dan bahan untuk kemah suci tersebut (Kel. 25:1-27:21) dan kemuliaan Allah memenuhi Kemah Suci tersebut (Kel. 40:35). Selanjutnya di dalam kitab 1 RajaRaja juga dapat dijumpai tentang Bait Suci dan istana yang dibangun oleh

1 Noh, Ibrahim Boiliu, and Saniogo Dakhi Menjadi Manusia Otentik (Jakarta: Hegel Pustaka, 2018), 1.

${ }^{2}$ Hugh J. Blair, Tafsiran Alkitab Masa Kini (Jakarta: Yayasan Komunikasi Bina Kasih, 2012), 121.
Salomo (1 Raj. 7-8), sejak dari awal perencanaan pun Allah sudah campur tangan. ${ }^{3}$ Dari penjelasan tersebut dapat diketahui bahwa teknologi sudah ada sejak zaman manusia diciptakan dan Allah sendiri adalah arsitek yang terlibat lansung dalam menciptakan teknologi.

Dalam hal ini, Allah tidak melarang manusia untuk menciptakan, menggunakan dan mengembangkan teknologi karena itu merupakan mandat yang Allah berikan kepada manusia untuk mengelolah alam semesta untuk kebetuhan manusia itu sendiri. Namun yang Allah sangat menentang manusia dalam menciptakan teknologi dengan motivasi yang salah. Hal ini terlihat jelas di Kitab Kejadian, Allah memporakporandakan kota Babel (Kej. 11:1-9). Dalam hal ini, yang ditentang Allah bukanlah pendirian kota dan menara Babel-nya, tetapi motivasi manusia dalam membangun adalah untuk mencari nama dan ingin menyamai Allah (Kej. 11:4). Di sini jelas bahwa Allah tidak mempermasalahkan teknologi namun yang Allah tentang itu adalah motivasi manusia dalam menciptakan teknologi.

Dalam Alkitab perintah yang Allah berikan kepada manusia walaupun perintah tersebut diberikan kepada Adam sebagai manusia pertama, namun perintah itu juga diberikan secara tidak langsung kepada seluruh manusia hingga saat ini. Dalam hal ini, Allah memperlengkapi manusia dengan akal budi sehingga lewat akal budi inilah manusia mengembangkan teknologi dengan cepat, sesuai

\footnotetext{
3 Benget Rumahorbo, "Pendaya Guna Ilmu Teknologi Di Tinjau Dari Sudut Pandang Iman Kriaten," Manajemen Informatika \& Komputerisasi Akuntansi Vol.1, No.1 (Maret 2015): 52, diakses 12 Mei 2020, http : //methomika. net/ index. php / jmika /issue/view/6.
} 
perkembangan zaman dan peradaban. Manusia terus menciptakan, menggunakan dan mengembangkan teknologi, sesuai dengan perkembangan zaman hingga saat ini di era revolusi industri 4.0 manusia menciptakan teknologi yang begitu canggih dan bisa digunakan untuk melakukan apa saja misalnya dengan teknologi manusia bisa mengubah laki-laki seutuhnya menjadi perempuan dan mengubah perempuan seutuhnya menjadi laki-laki, dengan teknologi manusia bisa menciptakan manusia melalui bayi tabung, dan manusia menciptakan teknologi yang bisa menggantikan manusia dalam melakukan aktivitas dan masih banyak contoh lain lagi.

Lahirnya teknologi digital di era revolusi industri 4.0 berdampak terhadap kehidupan manusia diseluruh dunia yang mana semua proses dilakukan secara sistem otomatisasi di dalam aktivitas melalui perkembangan teknologi internet semakin berkembang tidak hanya menghubungkan manusia seluruh dunia namun juga menjadi suatu basis bagi proses transaksi perdagangan dan transportasi secara online. ${ }^{4}$ Revolusi industri 4.0 secara fundamental mengakibatkan berubahnya cara manusia berpikir, hidup, dan berhubungan satu dengan yang lain. Era ini akan mendisrupsi berbagai aktivitas manusia dalam berbagai bidang, tidak hanya dalam bidang teknologi saja, namun juga bidang yang lain seperti ekonomi, sosial, dan politik serta agama. ${ }^{5}$

${ }^{4}$ Niko Sangaji, "Pengaruh Revolusi Industri 4.0 Pada Kewirausahaan Untuk Kemandirian Ekonomi," Seminar Nasional \& Call For Paper Seminar Bisnis Magister Manajemen (2019): 226 32, Diakses 19 Februari 2019, http://hdl.handle.net/11617/11088.

${ }_{5}^{5}$ Banu Prasetyo, and Umi Trisyanti. "Revolusi Industri 4.0 Dan Tantangan Perubahan Sosial IPTEK." Journal of Proceedings Series Vol.5,
Dalam hal ini, revolusi 4.0 membawa berbagai dampak negatif di antaranya ancaman pengangguran akibat otomatisasi, kerusakan alam akibat eksploitasi industri, serta maraknya hoax akibat mudahnya penyebaran informasi, dan juga penyimpangan terhadap iman atau keyakinan orang percaya. ${ }^{6}$ Oleh karena itu, kunci dalam menghadapi revolusi industri 4.0 adalah selain menyiapkan kemajuan teknologi, di sisi lain perlu dilakukan pengembangan sumber daya manusia dari sisi humaniora agar dampak negatif dari perkembangan teknologi dapat ditekan, serta pengajaran pendidikan agama untuk mengantisipasi penggunaan teknologi. Pendidikan agama Kristen merupakan pendidikan agama yang tepat untuk mengantisipasi penggunaan teknologi menurut iman Kristen melalui pengajaran, didikan dan pendampingan kepada orang percaya dalam penggunaan teknonologi sehingga orang percaya tidak menyalahgunakan teknologi tetapi tetap menggunakan teknologi sesuai dengan iman Kristen dan secanggih apa pun teknologi yang membuat semua serba instan tetapi iman orang percaya tetap beriman kepada Yesus.

Metode peneltian yang digunakan dalam penelitian ini adalah studi kepustakaan. Ini berarti bahwa penelitian ini mengacu pada data atau bahan tertulis yang berkaitan dengan topik diskusi yang diangkat, tentu saja penelitian ini menggunakan ide-ide tertulis sebagai sumber penekanan pada interpretasi dan analisis makna konsep pemikiran dalam bentuk ekspresi baik ide empiris dan ideide rasional. Sumber data dalam penelitian ini adalah kontak langsung

No.1 (2018): 22-27, diakses 17 Mei 2020, http//dx.doi.org/10.12962/j23546026.y2018i5.441 7.

${ }^{6}$ Prasetyo dan Trisyanti. Revolusi Industri 4.0. 
dengan gagasan pendidikan agama Kristen dan penggunaan teknologi menurut iman Kristen. Selain itu, penulis merujuk pada buku-buku oleh orang lain yang membahas wacana pendidikan berbasis keterbukaan untuk memfasilitasi pemahaman.

\section{Hasil dan Pembahasan}

\section{A. Perkembangan Teknologi Industri Revolusi 1.0-4.0.}

Teknologi merupakan semacam perpanjangan tangan manusia untuk dapat memanfaatkan alam dan sesuatu yang ada di sekelilingnya secara lebih maksimal. Dengan demikian, secara sederhana teknologi bertujuan untuk mempermudah pemenuhan kebutuhan manusia. Kata teknologi berasal dari bahasa Yunani, techne yang berarti 'keahlian' dan logika yang berarti pengetahuan. ${ }^{7}$ Dalam hal ini, teknologi secara sempit mengacu pada obyek benda yang digunakan untuk kemudahan aktivitas manusia, seperti mesin, perkakas, atau perangkat keras. Teknologi secara luas dapat meliputi sistem, organisasi, juga teknik. Akan tetapi, seiring dengan perkembangan dan kemajuan zaman, pengertian teknologi menjadi semakin meluas, sehingga saat ini teknologi merupakan sebuah konsep yang berkaitan dengan jenis penggunaan dan pengetahuan tentang alat dan keahlian, dan bagaimana ia dapat memberi pengaruh pada kemampuan manusia untuk mengendalikan dan mengubah sesuatu yang ada di sekitarnya.

Teknologi yang berkembang dengan pesat, meliputi berbagai bidang kehidupan manusia. Dalam hal ini, sulit memisahkan kehidupan manusia dengan

\footnotetext{
7 Rusman, Pembelajaran Berbasis Teknologi Informasi dan Komunikasi (Jakarta: Grafindo Persada, 2012), 78.
}

teknologi, bahkan sudah merupakan kebutuhan manusia. Perkembangan teknologi yang sebelumnya merupakan bagian dari ilmu atau bergantung dari ilmu, sekarang ilmu dapat pula bergantung dari teknologi. ${ }^{8}$ Teknologi mengalami perkembangan seiring dengan zaman yang berubah dan teknologi mempunyai ciri khas masing-masing di zamannya. Dalam penggunaan teknologi manusia menggunakan sesuai dengan kebutuhannya, agar dapat mempermudah aktivitas dalam kehidupan sehari-hari. Teknologi mengalami perkembangan yang sangat pesat dalam revolusi industri. ${ }^{9}$

Dengan demikian, ada empat perkembangan teknologi di era revolusi industri, yaitu: Pertama, revolusi industri 1.0 pertama kali terjadi di Inggris pada akhir abad ke-18 dan para ahli menemukan mesin uap, sinar $\mathrm{X},{ }^{10}$ mengembangkan bibit baru yang unggul dengan cara mutasi dan pupuk kimia serta obat hama penyakit. 11 Revolusi Industri 1.0 berlangsung periode antara tahun 1750-1850. ${ }^{12}$ Kedua, revolusi industri 2.0 kelanjutan yang tidak terpisahkan dari revolusi industri sebelumnya yang mulai di Inggris pada abad ke-18 ${ }^{13}$ dan ditandai dengan kemunculan pembangkit tenaga listrik dan motor pembakaran dalam (combustionchamber). Revolusi yang kedua ini terjadi pada akhir abad ke-19 di

\footnotetext{
${ }^{8}$ Muhamad Ngafifi. "Kemajuan Teknologi Dan Pola Hidup Manusia Dalam Perspektif Sosial Budaya." Pembangunan Pendidikan Fondasi Dan Aplikas Vol.2, No.1 (Maret 2014): 33-47, diakses 16 Mei 2020, https://doi.Org/10. 21831/ jppfa. v2i1.2616.

${ }^{9}$ Lukman Santoso Az, Para Penggerak Revolusi, Laksana (Yogyakarta, 2017), 33.

${ }^{10}$ Santoso, Para Penggerak Revolusi, 42.

${ }^{11}$ Santoso, Para Penggerak Revolusi, 42.

${ }^{12}$ Santoso, Para Penggerak Revolusi, 42.

${ }^{13}$ Santoso, Para Penggerak Revolusi, 42.
} 
mana mesin-mesin produksi yang ditenagai oleh listrik digunakan untuk kegiatan produksi secara masal. ${ }^{14}$ Penemuan ini memicu kemunculan pesawat telepon, mobil, pesawat terbang, dan lain-lain yang mengubah wajah dunia secara signifikan. ${ }^{15}$ Ketiga, revolusi industri 3.0 diawali dengan munculnya teknologi informasi dan elektronik yang masuk ke dalam dunia industri yaitu sistem otomatisasi berbasis komputer dan robot. Peralatan industri sudah tidak lagi dikendalikan oleh manusia, namun sudah dikendalikan oleh komputer atau lebih dikenal dengan istilah komputerisasi. ${ }^{16}$ Pada periode 1960-2010 melahirkan inovasi pengembangan sistem perangkat lunak untuk memanfaatkan perangkat keras elektronik. Keempat, revolusi Industri 4.0 pertama kali di Jerman pada tahun 2011 yang ditandai dengan revolusi digital yaitu robot kecerdasan buatan (artificial intelligence robotic), teknologi nano, bioteknologi, dan teknologi komputer kuantum, blockchain (seperti bitcoin), teknologi berbasis internet, dan printer $3 \mathrm{D} .^{17}$

\section{B. Pandangan Alkitab terhadap Teknologi}

Dalam Alkitab dapat dijumpai bahwa teknologi sudah ada sejak manusia

\footnotetext{
${ }^{14}$ Hoedi Prasetyo and Wahyudi Soetopo, "Industri 4.0: Telaah Klasifikasi Aspek Dan Arah Perkembangan Riset," Teknik Industri Vol.13, No.1 (Januari 2018): 17. Di akses Mei 19 2020, https://doi.org/10.14710/jati.13.1.17-26.

${ }^{15}$ Prasetyo dan Soetopo, Industri 4.0: Telaah, $17-$ 26.

${ }^{16}$ Hamdan, "Pengaruh Revolusi Industri Pada Kewirausahaan Demi Kemandirian Ekonomi," Nusamba Vol.3 No. 2 (Oktober 2018): 3. Di akses $20 \quad$ Mei 2020, https://doi.org/10.29407/nusamba.v3i2.12142.

${ }^{17}$ Slamet Rosyad, Revolusi Industri 4.0: Peluang dan Tantangan Bagi Alumni Universitas Terbuka, (Jakarta: Univesitas Sudirman, 2018), 1-2.
}

diciptakan. Dalam hal ini, Allah menciptakan manusia menurut gambar dan rupaNya (Imago Dei) dan memperlengkapi manusia dengan kekuatan berpikir (rasio) $\left(\right.$ Kej. 1:27-31) ${ }^{18}$ dengan tujuan agar manusia berpikir dan mampu menggali potensi alam untuk memenuhi kebutuhannya. Artinya teknologi yang kita lihat, rasakan, dan kembangkan saat ini sesungguhnya sudah ada di Alkitab meski tidak secanggih sekarang. ${ }^{19}$

Dalam kitab Kejadian kisah air bah, Allah memerintahkan Nuh membuat kapal untuk menyelamatkan dirinya dan keluarganya dari kebinasaan air bah. Dalam hal ini, kemampuan Nuh bukan berarti Allah tidak campur tangan dalam menentukan pembangunan kapal tersebut tetapi Allah menentukan dimensi ruang dalam kapal bahkan bahannya pun Allah yang menentukan (Kej. 6:14-15). ${ }^{20}$ Dalam Kitab Keluaran juga Musa diperintahkan Allah untuk membuat Kemah Suci (Kel. 25:9). Allah sendiri telah menjadi arsitek yang merencanakan ruang-ruang, dimensi dan bahan untuk kemah suci tersebut (Kel. 25:1-27:21) dan kemuliaan Allah memenuhi Kemah Suci tersebut (Kel. 40:35). Selanjutnya di dalam Kitab 1RajaRaja juga dapat dilihat tentang Bait Suci dan istana yang dibangun oleh Salomo (1Raj. 7-8), sejak dari awal perencanaan pun Allah sudah campur tangan. ${ }^{21}$ Dengan demikian, kita dapat ketahui bahwa teknologi sudah ada sejak zaman manusia diciptakan. Allah yang memerintahkan manusia untuk

\footnotetext{
${ }^{18}$ Boiliu and Dakhi, Menjadi Manusia Otentik, 1.

19 Drie S. Brotosudarmo, Teladan Kehidupan: Pendidikan Agama KristenReferensi KTSP dengan Kecerdasan Majemuk, peny. Dien Simiyatiningsih (Yogyakarta: Andi Offset, 2007), 125.

${ }^{20}$ Blair, Tafsiran Alkitab Masa Kini, 121.

21 Rumahorbo, Pendaya Guna Ilmu Teknologi, 52.
} 
menciptakan teknologi dan Allah sendiri sebagai arsitek yang terlibat lansung dalam menciptakan teknologi. Artinya bagwa yang menciptakan teknologi itu adalah manusia tetapi Allah yeng memerintahkan manusia untuk menciptakan teknologi dan membekali manusia dengan ilmu pengetahuan.

Dalam hal ini, Allah tidak melarang manusia untuk menciptakan teknologi, menggunakan dan mengembangkan karena itu merupakan mandat yang Allah berikan kepada manusia untuk mengelolah alam semesta untuk kebetuhan manusia itu sendiri. Namun yang Allah sangat menentang manusia dalam menciptakan teknologi, mengunakan dan mengembangkan dengan motivasi yang salah. Hal ini terlihat jelas di Kitab Kejadian Allah memporak-porandakan kota Babel (Kej.11:1-9). Dalam hal ini, yang ditentang Allah bukanlah pendirian kota dan menara Babel-nya, tetapi motivasi mereka dalam membangun adalah untuk mencari nama dan ingin menyamai Allah (Kej. 11:4). ${ }^{22}$ Pada zaman Salomo, Allah menghukum bangsa Israel karena kemewahan, gemerlap teknologi di zamannya telah disalah gunakan oleh Salomo untuk mengoleksi wanita asing sehingga dia kemudian jatuh kepada penyembahan berhala (1Raj. 11:1-13). ${ }^{23}$ Di zaman Yesus, ketika murid-murid menunjuk pada bangunan Bait Suci Yesus mengatakan bahwa bangunan tersebut akan diruntuhkan, apabila tidak

${ }^{22}$ Douglas J. D, Ensiklopedia Alkitab Masa Kini, jIlid II M2, (Jakarta: Yayasan Komunikasi Bina Kasih, 2000), 78.

${ }^{23}$ Evi Tobeli and Zefiana F. Zelda, "Pemahaman Remaja Kristen Dalam Menghadapi Perkembangan Ilmu Pengetahuan dan Teknologi (IPTEK)" Penabiblos Vol.5 No.1 (April 2017): 76-77, diakses 20 Mei 2020, http://www.ejurnal.ukrimuniversity.ac.id/detail.php?id_konten $=308 \&$ id_jurnal=4\&id_volume $=59$. digunakan sebagaimana mestinya untuk memuliakan Allah (Mat. 24:1-2). Di zaman Yesus juga dapat dijumpai dalam Alkitab Perjanjian Baru bahwa Yesus menentang penyalahgunaan fungsi Bait Suci yang dibangun selama empat puluh enam tahun menjadi arena komersil (Yoh. 2:16). 24 Dengan demikian, Allah menentang manusia dalam menciptakan teknologi ialah penyimpangan atau motivasi manusia dalam menciptakan teknologi untuk menyombongkan diri, meyalahgunakan teknologi dan menyamakan diri dengan Allah.

\section{Penggunaan Teknologi Menurut Iman Kristen}

Dalam pandangan Alkitab terhadap teknologi, jika dihubungkan dengan ayat dalam Alkitab yang berbicara tentang penentangan Allah terhadap teknologi maka dapat diketahui bahwa teknologi memang tidak bersalah, teknologi muncul karena kemampuan olah pikir yang diberikan Allah kepada manusia. 25 Sehingga manusia menciptakan, menggunakan dan mengembangkan teknologi. Namun semuanya itu dibawa kontrolnya Allah. Artinya manusia yang menciptakan, menggunakan dan mengembangkan namun tetap dibawa kobtrolnya Allah dengan tujuan agar manusia tidak menciptakan teknologi untuk menyombongkan diri atau menyamakan diri dengan Allah tetapi untuk kebutuhan manusia dan untuk kemuliaan Tuhan. Dalam hal ini, walaupun perintah tersebut diberikan kepada Adam sebagai manusia pertama, namun perintah itu juga diberikan secara tidak langsung kepada

\footnotetext{
${ }^{24}$ Tobeli dan Zelda, Pemahaman Remaja Kristen, 76-77.

${ }^{25}$ Tobeli dan Zelda, Pemahaman Remaja Kristen, 53.
} 
seluruh manusia hingga saat ini. Artinya Allah memperlengkapi manusia dengan akal budi, pikiran dan perasaan sehingga lewat akal budi inilah manusia mengembangkan teknologi dengan cepat, sesuai perkembangan zaman dan peradaban.

Dalam Alkitab mengatakan, "Baiklah orang bijak mendengar dan menambah ilmu dan baiklah orang yang berpengertian memperoleh bahan pertimbangan" (Ams. 1:5). Dalam hal ini, Allah sebenarnya menghendaki manusia untuk terus mengembangkan diri, menambah ilmu dan pengertian. Sebagai orang Kristen tetap menerima segala kemajuan teknologi yang ada dengan dasar Iman Kristen, yaitu takut akan Tuhan. Hal ini berarti bahwa tidak perlu menjauhi teknologi tapi justru terus mengembangkannya menjadi lebih baik lagi. Sebab Tuhan sendiri yang memberikan pengertian dan pengetahuan, keahlian, dalam berbagai pekerjaan kepada seseorang (Kel. 35:31). Sebagai mitra Allah maka manusia diberi kemampuan untuk mengetahui namun tetap dalam rasa hormat dan tunduk terhadap otoritas Allah Sang Pencipta (Ams.1:7). Iman Kristen memberikan dasar kepada kita untuk menerima perkembangan teknologi yang ada dalam iman Kristen yang menjadi dasar adalah Tuhan (Allah adalah arsitek).

Dengan demikian, ada beberapa hal yang perlu orang Kristen lakukan dalam penggunaan teknologi yang sesuai dengan iman Kristen, yaitu:

- Pertama Allah adalah sumber pengetahuan (Ams. 1:7) "Takut akan TUHAN adalah permulaan pengetahuan". Dalam hal ini, pengetahuan itu berasal atau bersumber dari Tuhan dan sikap diri yang takut akan Tuhan akan menghasilkan pengetahuan yang benar serta dapat menggunakan pengetahuan tersebut dengan bijak untuk mengabdi kepada Tuhan dan kebaikan bagi sesama. Dengan demikian, pengetahuan tersebut berasal dari Allah, maka teknologi memiliki keterbatasan. Artinya seluruh ciptaan Allah atau yang berasal dari Allah memiliki keterbatasan, hanya Allah sendirilah yang sempurna dan tidak terbatas. Secanggih apa pun teknologi yang terus berkembang, dan hebatnya teknologi yang ada sekarang ini, tetap saja tidak dapat membuktikan keberadaan Allah. Keberadaan Allah dan kehadiran-Nya dalam diri orang percaya hanya dapat dipahami dengan iman.

Kedua sebagai orang Kristen harus dapat menguasai teknologi dan bukan dikuasai oleh teknologi (1 Kor. 6:12). "Segala sesuatu halal bagiku, tetapi bukan semuanya berguna. Segala sesuatu halal bagiku, tetapi aku tidak akan membiarkan diriku diperhamba oleh suatu apapun." Dalam hal ini, teknologi hasil dari akal budi manusia diizinkan digunakan untuk mengupayakan kebaikan dan kesejahteraan hidup manusia. Akan tetapi, ketika teknologi yang merupakan hasil dari akal budi manusia yang telah dianugerahkan Allah kepada manusia itu telah digunakan untuk menentang hukum Tuhan, maka manusia akan kembali menjadi budak dosa. Allah tentunya akan memberikan hukuman kepada manusia yang telah menjadi budak dosa dengan membuat teknologi sebagai "allah", yang karenanya manusia telah diperhamba. Seperti halnya Allah mengacaukan upaya orang-orang Babel yang membangun kota dan mendirikan menara dengan 
motivasi untuk mencari nama dan melawan Allah.

\section{Pendidikan Agama Kristen Antisipatif Penggunaan Teknologi}

\section{Pendidikan agama Kristen di keluarga}

Pendidikan agama Kristen
memiliki peran penting untuk mengantisipasi penggunaan teknologi menurut iman Kristen di era revolusi industri 4.0 melalui pengajaran PAK di lingkungan keluarga. Dalam hal ini, keluarga merupakan lingkungan yang terutama melakukan pembentukan sosial anak untuk menentukan tujuan seorang anak dan tempat tumbuh kembang. Pendidikan agama Kristen dalam keluarga sangat penting, agar setiap orang tua mengerti bagaimana memperlakukan dan cara pendampingan kepada anak-anak. ${ }^{26}$ menurut Marhin Luther yaitu melibatkan semua warga jemaat, khususnya kaum muda dalam rangka belajar teratur dan tertib agar semakin sadar akan dosadosanya. ${ }^{27}$ Senada dengan hal ini, menurut Janse Belandina pendidikan Agama Kristen dalam keluarga bertujuan untuk: (a) Mengalami proses pertumbuhan sebagai pribadi dewasa dalam segala aspek. (b) Mampu mengidentifikasi berbagai pergumulan dalam keluarga serta kaitannya dengan pengaruh modernisasi. (c) Mampu menjelaskan makna kebersamaan dengan orang lain tanpa harus kehilangan identitasnya sebagai orang Kristen yang percaya kepada Yesus Kristus. (d) Mampu mewujudkan nilai-nilai Kristiani

${ }^{26}$ Djoys Anneke Rantung, "Pendidikan Agama Kristen Untuk Keluarga Menurut Pola Asuh Keluarga Ishak Dalam Perjanjian Lama”, Jurnal Shanan Vol.3 No. 2 (Oktober 2019): 63-65.

27 Robert R. Boehlke, Sejarah Perkembangan Pikiran Dan Praktek Pendidikan Agama Kristen (Jakarta: BPK-Gunung Mulia, 2009), 20. dalam menghadapi gaya hidup modern. (e) Mampu mengkritisi perkembangan budaya dan IPTEK. ${ }^{28}$

Peran pendidikan agama Kristen dalam keluarga sangat penting diterapkan oleh orang tua di era 4.0. Salah satu peran pendidikan agama Kristen dalam keluarga saat ini adalah mengupayakan kerjasama orang tua ayah dan ibu dalam mendidik anak serta menciptakan keharmonisan dalam keluarga. Peran orang tua di era revolusi industiri 4.0 saat ini adalah bagaimana orang tua mengajar, mendidik dan mendampingi anak-anak dalam penggunaan teknologi sehingga mereka tidak menyalahgunakan teknologi namun tetap menggunakan teknologi menurut iman Kristen. Dalam hal ini, anak-anak zaman sekarang yang berada pada zaman teknologi sangat canggih, yang ditandai dengan Smartphone, Internet, Facebook, Twitter, Whatshapp, Line, Instagram, games online, dll. Orang tua memiliki peran yang sangat penting untuk mengantisipasi penggunaan teknologi sehingga walaupun zaman semakin berkembang dan teknologi semakin canggih tetap mereka beriman kepada Yesus Kristus. Dengan demikian orang tua harus menyadari bahwa keluarga merupakan tempat pertama dan utama bagi anak belajar tentang iman dan menjadi dasar bagi hidup iman mereka. Sebagai orangtua merekalah yang menyiapkan dan memberikan bekal kehidupan bagi anak-anak dalam keluarga. Bekal kehidupan itulah yang menentukan hidup dan kehidupan anak di masa depan. Bukan bekal dalam arti materi, tetapi lebih pada hal-hal rohani, yaitu iman yang hidup, kasih yang sejati,

\footnotetext{
${ }^{28}$ Talizaro Tafonao, "Peran Pendidikan Agama Kristen Dalam Keluarga Terhadap Perilaku Anak, " Edudikara: Pendidikan Dan Pembelajaran Vol.3, No.2 (Mei 2018): 126. Di akses 20 Mei 2020, Doi: 10.5281/zenodo.2783994.
} 
sikap hati, kepekaan terhadap sesama, cara berpikir dan berbicara, kekuatan mental, daya juang untuk hidup dan daya tahan terhadap godaan serta bertindak bijaksana.

Dalam hal ini, setiap orang tua yang ingin memahami dan mendidik anak-anak, haruslah memahami dunia mereka. Orang tua tidak dapat menutup diri dan menarik diri dari kenyataan yang sedang terjadi bahwa secara tidak langsung juga telah terlibat di dalam pengaruh era globalisasi. Ada banyak reaksi orang tua dalam menyikapi tantangan globalisasi ini khususnya perkembangan dalam dunia teknologi; dari orang tua yang sangat ketakutan, tidak peduli, hingga yang sangat terbuka terhadap perkembangan ini. "Reaksireaksi tersebut dikategorikan menjadi tiga, yaitu; menarik diri (Bubble Way), menyerahkan diri (EGP-Emang Gue Pikirin) dan menerima dengan kritis (Smart Way). ${ }^{29}$ Oleh karena itu, orang tua memiliki peran yang sangat penting dalam keluarga untuk menagantisipasi penggunaan teknologi pada anak melalui pengajaran pendidikan agama Kristen melalui bebarpa hal yang harus orang tua lakukan yaitu:

\section{a. Orang tua sebagai pengajar}

Peran orang tua dalam keluarga sebagai pengajar untuk mengajar anak dalam penggunaan teknologi menurut iman Kristen. Dalam hal ini, sebagai pengajar Orang tua harus mengajar dengan membicarakannya sebagaimana dalam Alkitab (Ul. 11:19) "Kamu harus

29 Elsyana Nelce Wadi and Elisabet Selfina, "Peran Orang Tua Sebagai Keluarga Cyber Smart Dalam Mengajarkan Pendidikan Kristen Pada Remaja GKII Ebenhaezer Sentani Jayapura Papua," Jaffray Vol.14, No.1 (April 2016): 80, diakses $20 \quad$ Mei 2020, https://doi.org/10.25278/jj71.v14i1.190. mengajarkannya kepada anak-anakmu dengan membicarakannya, apabila engkau duduk di rumahmu dan apabila engkau sedang dalam perjalanan, apabila engkau berbaring dan apabila engkau bangun." Artinya orang tua bertanggung jawab membicarakan firman Tuhan kepada anak dan berusaha untuk menuntun setiap anak kepada hubungan yang setia dengan Tuhan. Tujuan dari membicarakan firman Tuhan kepada anak ialah mengajarnya untuk takut akan Tuhan, berjalan pada jalan-Nya, mengasihi dan menghargai Dia serta melayani Dia dengan sepenuh hati dan jiwa (Ul. 4:6). Dalam membicarakan firman Tuhan kepada anak membutuhkan waktu yang baik dan tepat, namun untuk mendapatkan waktu, di generasi ini sangat susah karena keseharian anak akan dipenuhi dengan alat-alat digital berupa handphone, gadget, Notebook, Smartphone, dan lainnya. Selain itu, anak juga akan banyak menghabiskan waktu bersama dengan teman-teman sebayanya di luar rumah. Oleh karena itu, firman Tuhan di dalam Ulangan mengatakan bahwa membicarakan firman Tuhan kepada anak-anak bukan hanya ketika sedang berada di dalam rumah saja melainkan pada waktu bangun pagi, pada waktu bersama di luar rumah dan bahkan pada waktu akan tidur di malam hari. Artinya orang tua selain mengajar dengan membicarakan secara lansung juga bisa mengajar melalui gadget dengan tujuan agar anak tidak salah menggunakan teknologi, namun tetap menggunakan teknologi sesuai iman Kristen.

\section{b. Orang tua sebagai pendidik}

Orang tua memiliki peran yang sangat penting dalam keluarga untuk mendidik anak dalam penggunaan teknologi menurut iman Kristen. Dalam hal ini, didikan dari orang tua sangat 
menentukan kehidupan anak dalam penggunaan teknologi. Artinya anak menggunakan teknologi sesuai iman Kristen atau tidak tergantung didikan dari orang tua. Mendidik anak dalam penggunaan teknologi merupakan suatu tugas yang besar bagi orang tua dalam menuntunnya untuk memiliki potensi yang bermanfaat bagi generasi ini, jika orang tua tidak dengan sadar mendidik anak dalam penggunaan teknologi yang baik, maka anak akan menjadi budak teknologi dan mentuhankan teknologi. Hal yang sangat mendasar bagi orang tua untuk mendidik harus berdasarkan firman Tuhan. "Setiap orang tua perlu mengklarifikasi dan mengajarkan nilainilai luhur keimanan ataupun moralitas kepada anak-anaknya serta mengkondusifkan proses interialisasinya (proses diterima dan tertanamnya nilai dalam diri seorang anak). Dengan demikian, sebagai pendidik dalam keluarga ada beberapa hal yang dapat dilakukan oleh orang tua dalam hal mendidik anak yaitu: ${ }^{30}$ (a) Membentuk rutinitas sehari-hari keluarga dengan menyediakan waktu dan tempat yang cukup untuk belajar dengan anak-anak dan menugaskan tanggung jawab untuk tugas-tugas di dalam keluarga. (b) Memantau kegiatan di luar sekolah, misalnya menetapkan batasan penggunaan teknologi, mengurangi waktu bermain gadget, dan memantau temantemannya yang bergaul dengan anaknya. (c) Orang tua harus menciptakan lingkungan rumah yang mempromosikan

\footnotetext{
${ }^{30}$ Adewumi M. Grace, "Olojo Oludare Jethro, Falemu Funke Aina, "Roles Of Parent On The Academic Performance Of Pupils In Elementary Schools," International Journal of Academic Research in Business and Social Sciences Vol.2, No.1 (January 2012): 197. Diakses pada 20 Mei 2020, https://portal.issn.org/resource/issn/22226990.
}

pembelajaran, memperkuat apa yang diajarkan di sekolah dan mengembangkan keterampilan hidup sehingga anak-anak perlu menjadi orang dewasa yang bertanggung jawab.

\section{c. Orang tua sebagai pendamping (mentoring)}

Orang tua memiliki peran yang sangat penting dalam keluarga sebagai pendamping. Dalam hal ini sebagai pendamping orang tua harus mengontrol anak dalam penggunaan teknologi sehingga tidak salah menggunakan tetapi tetap menggunakan sesuai dengan yang sudah orang tua ajarkan. Pendampingan orang tua terhadap anak dalam penggunaan teknologi yang efektif harus memberikan disiplin pada anak sebagai mana pengajaran dari orang tua terhadap anak-anak dalam Perjanjian Lama menurut Kitab Amsal adalah "kedisiplinan" (Ams. 3:11-12; 19:15; 22:15). Kitab Amsal memberi penekanan yang sangat besar pada disiplin dan benar-benar menaruh perhatian sehingga disiplin dijalankan bersamaan dengan hukuman di dalamnya. Disiplin berarti harus meneladani apa yang Tuhan ajarkan berdasarkan hukum Taurat dan apabila anak lalai melakukannya maka akan diberlakukan hukuman, namun hukuman ini berjalan bukan berdasarkan kemarahan melainkan berdasarkan kasih (Ams. 3:1112).

Disiplin berbicara mengenai banyak hal yang dapat dilakukan oleh orang tua kepada anak yang berhubungan dengan alat komunikasi, media dan teknologi informasi yang digunakan. Dengan demikian, ada beberapa langkah dalam mendisiplinkan anak yang perlu dilakukan, yaitu: 31 (a) Tetapkan

\footnotetext{
31 Hellen C. Pratama, Cyber Smart Parenting (Bandung: Visi Anugerah Indonesia, 2012), 87.
} 
batas/aturan, setiap orang tua bertanggung jawab untuk memberikan batasan/aturan kepada anak dalam beraktifitas dengan gadget. Dalam hal ini, "aturan atau batas adalah sebuah pagar perlindungan yang akan memberikan rasa aman bereksplorasi kepada setiap anak di masa pertumbuhannya." Dengan demikian, orang tua harus dengan tegas memberikan batasan atau aturan kepada anak dalam penggunaan internet dan alat komunikasi. Misalnya; anak diijinkan untuk bermain dengan gadget atau internet hanya setelah selesai mengerjakan tugas rumahnya, dalam menonton televisi juga dibatasi hanya beberapa jam dalam sehari. (b) Pengawasan, orang tua sangat diharapkan untuk dapat mengawasi anak dalam menggunakan internet dan gadgetnya. Dalam hal ini, ada baiknya jika orang tua memasang filter pada situs-situs tertentu yang kurang baik untuk ditonton pada notebook dan sebaiknya orang tua juga harus dapat melihat isi dari gadget anaknya.

\section{Pendidikan Agama Kristen di Gereja}

Keberadaan dan kemajuan teknologi di era revolusi 4.0 sangat membantu manusia untuk menyelesaikan berbagai pekerjaan yang lebih efisien dan lebih baik. Dalam perkembangan media komunikasi ini, gereja ikut serta membudidayakan media tersebut dalam praktek pelayanannya. Secara khusus media elektronik yang sangat berkembang saat ini, gereja membudidayakannya untuk memfasilitasi pertumbuhan iman umat. Dalam hal ini, tidak dapat dipungkiri bahwa setiap bentuk media komunikasi khususnya elektronik, memiliki dampak positif dan negatif. Gereja perlu mengantisipasi pengaruh perkembangan media ini agar tidak menjadi batu sandungan bagi pertumbuhan iman jemaat karena sangat disayangkan dengan tujuan yang baik tetapi justru dapat menghancurkan esensi persekutuan itu sendiri. ${ }^{32}$

Pendidikan agama Kristen memiliki peran yang sangat penting di gereja untuk mengantasipasi penggunaan teknologi pada jemaat sehingga mereka tidak salah menggunakan teknologi tetapi menggunakannya menurut iman Kristen. ${ }^{33}$ Pendidikan agama Kristen yang dilakukan di gereja dalam berbagai kategori usia yakni dari anak sampai lansia. Dalam hal ini, gereja berperan dalam pendidikan Kristen, baik itu melalui pengajaran maupun keteladanan hidup anggota jemaat yang dapat memberi didikan kepada jemaat yang membutuhkan pendidikan agama Kristen. ${ }^{34}$ Gereja tidak hanya mendidik melalui pengajaran Kristen tetapi juga melalui kehidupan nyata. Menurut Iris V Cully pendidikan agama Kristen "sejak permulaan gereja telah menjadi masyarakat yang mengajar." 35 Artinya di manapun dan kapan saja gereja merupakan masyarakat yang tetap meneruskan pengajaran. Gereja tidak hanya mengajar tetapi juga melalui keteladanan hidup, baik melalui pendeta

\footnotetext{
${ }^{32}$ Fredik Melkias Boiliu, "Pendidikan Agama Kristen Yang Antipatif dan Hoaks Di Era Digital: Tinjauan Literatur Review," Gema Wiralodra Vol.11, No. 1 (April 2020), 166. Diakses pada 20 Mei 2020 , https://doi.org/10.31943/gemawiralodra.v11i1.114 33 Johanes Wesley Hasugian, "Kurikulum dan Pembelajaran Warga Jemaat Dewasa di Gereja," Kurios Vol.5 No.1 (April 2019), 40, diakses pada $20 \quad$ Mei 2020. https://doi.org/10.30995/kur.v5i1.96.

${ }^{34}$ Desi Sianipar, "Penggunaan Pendekatan Shared Christian Praxis (SCP) Dalam Pendidikan Agama Kristen Di Gereja," Jurnal Shanan Vol.3 No.2 (Oktober 2019): 116. Diakses pada 20 Mei 2020, http://ejournal.uki.ac.id/index.php/shan/article/vie w/1582.

${ }^{35}$ Iris V. Cully, Dinamika Pebdidikan Kristen (Jakarta: BPK-Gunung Mulia, 2006), 3.
} 
atau gembala-gembala sidang, majelis dan anggota jemaat juga dapat menolong jemaat dalam mengunakan teknologi sesuai dengan nilai-nilai Kristiani atau iman Kristen.

Dalam hal ini, pendidikan agama Kristen memiliki peran yang sangat penting di gereja melalui pengajaran untuk mengantisipasi penggunaan teknologi sehingga jemaat tidak salah menggunakan teknologi. Dengan demikian, yang perlu gereja mengajarkan kepada jemaat dalam penggunaan teknologi melalui beberapa hal yaitu: Pertama, menggunakan teknologi sesuai fungsi dan daya kemampuan bukan persaingan. Kedua, teknologi adalah alat bukan tujuan jadi jangan memberhalakan teknologi atau menggunakan teknologi secara berlebihan sehingga menimbulkan gaya saing di antara setiap orang. ${ }^{36}$ Ketiga tidak boleh membiarkan kemajuankemajuan teknologi menjadi objek yang keliru dan meninggalkan ketergantungan kepada Allah (Kej. 11:1-9). ${ }^{37}$

Setelah gereja mengajarkan kepada jemaat dalam penggunaan teknologi maka perlu juga mengajarkan mereka dalam bertanggung jawab menggunakan teknologi. Dalam hal ini, sikap bertanggung jawab dalam mengunakan teknologi merupakan hal yang harus di pahami oleh jemaat dalam menggunakan teknologi. Adapun hal-hal yang harus dipahami oleh jemaat berkaitan dengan sikap tanggung jawab dalam menggunakan teknologi adalah sebagai beriku: Pertama, Takut akan Tuhan (Ams. 1:7), artinya dalam penggunaan teknologi harus disertai hati nurani, dibangun dengan kesadaran dan kebenaran untuk kehidupan banyak

\footnotetext{
${ }^{36}$ Celia D. Drummond, Teologi Dan Ekologi (Jakarta: BPK-Gunung Mulia, 2001), 113.

${ }^{37}$ Tobeli, Pemahaman Remaja Kristen, 78.
}

orang. ${ }^{38}$ Dengan demikian, segala sesuatu yang diciptakan atas dasar takut akan Tuhan, tentunya dalam pengembangannya akan selalu melihat dari segi-segi dampak yang berguna bagi kehidupan manusia dan selalu melihat dari ukuran nilai dan norma yang berlaku. ${ }^{39}$ Kedua, jemaat harus menyadari bahwa teknologi adalah tugas. Dalam hal ini, jemaat harus memiliki sikap yang bertanggung jawab terhadap tugas yang diberikan Allah kepada manusia sebagaimana tertulis dalam (Kej. 1:28) "Allah memberkati mereka, lalu Allah berfirman kepada Amereka: "beranak cuculah dan bertambah banyak; penuhilah bumi dan taklukkanlah itu, berkuasalah atas ikan di laut dan burung-burung di udara dan atas segala binatang yang merayap di bumi." Artinya Tuhan memerintahkan manusia untuk menguasai segala yang ada di bumi termasuk teknologi untuk memuji dan memuliakan nama Tuhan. Ketiga, jemaat harus menggunakan teknologi sesuai dengan nilai moral. Dalam hal ini, setiap orang percaya dapat menggali dan mempergunakan teknologi sesuai dengan nilai-nilai moral, dengan taat dan bertanggung jawab kepada norma-norma Allah. Teknologi juga digunakan harus sesuai dengan norma-norma yang berlaku di dalam masyarakat. Penyalahgunaan teknologi dapat ditahan oleh penggunaan teknologi secara positif sesuai dengan norma-norma Tuhan dan dengan perjuangan memberantas penyalahgunaan teknologi. Nilai moral berkaitan dengan pribadi manusia. $^{40}$

\section{Pendidikan Agama Kristen di Sekolah}

Kehadiran teknologi di era revolusi industri 4.0 yang serba cepat dan

\footnotetext{
${ }^{38}$ Tobeli, Pemahaman Remaja Kristen, 78.

${ }^{39}$ Tobeli, Pemahaman Remaja Kristen, 78.

${ }^{40}$ Tobeli, Pemahaman Remaja Kristen, 86-87.
} 
canggih merupakan suatu tantangan dan peluang bagi guru dan siswa di sekolah. Dalam hal ini, peluang dalam teknogi bagi guru dan siswa adalah menggunakan teknologi sebagai media pembelajaran untuk menjadi metode dalam proses belajar mengajar, sedangkan yang menjadi tantangan ialah penyalahgunaan teknologi oleh siswa-siswa terhadap halhal yang merusak moral dan spiritual mereka. Hal ini merupakan tugas dan tanggung jawab seorang guru di sekolah khusunya guru pendidikan agama Kristen yang mengajarkan pendidikan agama Kristen. Pendidikan agama Kristen di sekolah memiliki peran yang sangat penting untuk mengantisipasi penyalahgunaan teknologi yang tidak sesuai dengan iman Kristen.

Dalam hal ini, Guru PAK merupakan unsur penting dalam mengajar di bidang Pendidikan Agama Kristen, terutama di sekolah demi pertumbuhan iman siswa. Di Era revolusi industri 4.0 merupakan era di mana siswa dengan mudah dapat mengakses apa saja yang ia inginkan sehingga hal ini akan sangat berpengaruh terhadap pertumbuhan iman mereka. Di sinilah peranan guru pendidikan agama Kristen sangat diperlukan untuk berperan aktif dalam mengarahkan siswa mengalami pertumbuhan iman. Peranan guru pendidikan agama Kristen di sekolah sangat membantu siswa untuk mengenal Yesus Kristus secara pribadi. Selain dari itu, guru merupakan tenaga pendidik yang memiliki tanggung jawab serta intensitas pertemuan yang tinggi dengan siswa dalam kehidupan sehari-hari.

Peran guru pendidikan agama Kristen di sekolah untuk mengantisipasi penggunaan teknologi pada siswa yaitu: Pertama, guru PAK harus mengajarkan kepada siswa tentang penggunaan teknologi yang baik dan benar berdasarkan standar kebenaran Firman Tuhan. Kedua, guru PAK harus mengkonseling siswa-siswi yang sudah kecanduan teknologi dan yang belum kecanduan sehingga mereka tetap menggunakan teknologi sesuai dengan kebutuhan. Ketiga, guru PAK harus megontrol siswa dalam penggunaan teknologi yang mana di sekolah siswa tidak boleh menggunakan handphone pada saat belajar. Selain itu, guru harus membangun kerja sama dengan orang tua untuk mengontrol siswa dalam penggunaan teknologi di rumah.

\section{Kesimpulan}

Sesuai dengan pembahasan tentang teknologi dalam pembelajaran pendidikan agama Kristen yang antisipatif di era revolusi indusri 4.0 maka dapat disimpulkan bahwa untuk mengantisipasi penyalahgunaan teknologi sehingga teknologi digunakan menurut iman Kristen maka perlu peran pendidikan agama Kristen melalui pengajaran yang di lakukan di lingkungan keluarga, gereja dan sekolah. Dalam hal ini, peran pendidikan agama Kristen yang dilakukan dalam keluarga untuk mengantisipasi penggunaan teknologi melalui peran orang tua dalam keluarga. Peran yang orang tua harus lakukan dalam keluarga melalui peran pendidikan agama Kristen yakni orang tua berperan untuk mengajar, mendidik, dan mendampingi anak dalam penggunaan teknologi sehingga anak tidak menyalahgunakan teknologi namun tetap menggunakan teknologi sesuai dengan iman Kristen. Peran pendidikan agama Kristen di gereja untuk mengantisipasi penggunaan teknologi menurut iman Kristen melalui tugas dan tanggung jawab gereja untuk mengajarkan kepada jemaat dari anak sampai lansia dalam menggunakan teknologi sesuai dengan iman Kristen 
yakni untuk keselamatan dan kemuliaan Tuhan dan juga menjelaskan bahwa Allah sangat menentang penyalahgunaan teknologi atau mentuhanan teknologi. Peran pendidikan agama Kristen di sekolah merupakan tugas dan tanggung jawab guru pendidikan agama Kristen untuk mengajar, mendisiplin dan mengkonseling siswa di sekolah dalam penggunaan teknologi sehingga mereka tidak salah menggunakan teknologi tetapi menggunakan teknologi sesuai dengan kebutuhan dan untuk memuliakanTuhan.

\section{Referensi}

Boiliu, Noh Ibrahim, \& Saniogo, Dakhi. Menjadi Manusia Otentik. Jakarta: Hegel Pustaka, 2018.

Boiliu, Fredik Melkias. "Pendidikan Agama Kristen Yang Antipatif Dan Hoaks Di Era Digital: Tinjauan Literatur Review." Gema Wiralodra Vol.11, No.2 (April 2020), 166. Diakses $20 \quad$ Mei 2020, https://doi.org/10.31943/gemawiralo dra.v11i1.114.

Boehlke, Robert R. Sejarah Perkembangan Pikiran Dan Praktek Pendidikan Agama Kristen. Jakarta: BPK-Gunung Mulia, 2006.

Benget, Rumahorbo. "Pendayagunaan Ilmu Teknologi Komputer Ditinjau Dari Sudut Iman Kristen." Methodika Vol.1, No. 1 (Maret 2015): 52. Diakses 12 Mei 2020, http : //methomika. net/ index. php / jmika /issue/view/6.

Cully, Iris V. Dinamika Pendidikan Kristen. Jakarta: BPK-Gunung Mulia, 2006.

Deane, Drummond Celia. Teologi Dan Ekologi. Jakarta: BPK-Gunung Mulia, 2001.

Soetopo, Critianto. Pendidikan Agama
Kristen Untuk Perguruan Tinggi. Yogyakarta: Yayasan Taman Pustaka Indonesia, 2017.

Hasugian, Johanes Wesley. "Kurikulum dan Pembelajaran Warga Jemaat Dewasa di Gereja." Kurios Vol.5, No.1 (April 2019), 40. Diakses pada $20 \quad$ Mei 2020. https://doi.org/10.30995/kur.v5i1.96

Hugh J. Blair. Tafsiran Alkitab Masa Kini. Jakarta: Yayasan Komunikasi Bina Kasih, 2012.

Kurtis A, Kenneth. 100 Peristiwa Penting Dalam Sejarah Kristen. Jakarta: BPK-Gunung Mulia, 2003.

Hamdan. "Pengaruh Revolusi Industri Pada Kewirausahaan Demi Kemandirian Ekonomi." Nusamba Vol.3, No.2 (Oktober 2018): 3. Diakses $20 \quad$ Mei 2020. https://doi.org/10.29407/nusamba.v $3 \mathrm{i} 2.12142$.

Laksana, Santoso, A. Z. Para Penggerak Revolusi. Yogyakarta: Pustaka Yustisia 2017.

Moradeke, Adewumi. "Roles Of Parent On The Academic Performance Of Pupils In Elementary Schools." International Journal of Academic Research in Business and Social Sciences Vol 2 No 1, 2012: 197. Di akses pada 20 Mei 2020. https://portal.issn.org/resource/issn/ 2222-6990.

Ngafifi, Muhamad. "Kemajuan Teknologi Dan Pola Hidup Manusia Dalam Perspektif Sosial Buday." Pembangunan Pendidikan: Fondasi Dan Aplikasi, Vol 2. No1, 2014, 33-47. Di akses 16 Mei 2020. https://doi.Org/10. 21831/ jppfa. v2i1.2616.

Pratama Hellen, Chou. Cyber Smart Parenting, Bandung: Visi Anugerah 
Indonesia, 2012.

Rusman. Pembelajaran Berbasis Teknologi Informasi Dan Komunikasi, Jakarta: Grafindo Persada, 2012.

Rantung, Djoys Anneke. "Pendidikan Agama Kristen Untuk Keluarga Menurut Pola Asuh Keluarga Ishak Dalam Perjanjian Lama." Jurnal Shanan, Vol 3 No 2 (Oktober 2019).

Sangaji, Niko, Vincent Hadi Wiyono, and Tri Mulyaningsih. "Pengaruh Revolusi Industri 4.0 Pada Kewirausahaan Untuk Kemandirian Ekonomi." Seminar Nasional \& Call For Paper Seminar Bisnis Magister Manajemen, 2019, 226-32. Diakses Mei 2010. http://hdl.handle.net/11617/11088.

Satya,Venti Eka. "Kajian Singkat Terhadap Isu Aktual Dan Strategis Strategi Indonesia Menghadapi Industri 4.0." Kajian Singkat Terhadap Isu Aktual Dan Strategis Strategi Indonesia Menghadapi Industri 4.0, Vol 9 No (2018)

Slamet, Rosyad. Revolusi Industri 4.0 : Peluang Dan Tantangan Bagi Alumni Universitas Terbuka. Jakarta: Univesitas Sudirman, 2018.

Sianipar, Desi. "Penggunaan Pendekatan Shared Christian Praxis (SCP) Dalam Pendidikan Agama Kristen Di Gereja." Jurnal Shanan Vol 3 No 2, (Oktober 2019), 116. Diakses pada $20 \quad$ Mei 2020. http://ejournal.uki.ac.id/index.php/s han/article/view/1582.

Soetopo Wahyudi, \& Hoedi Prasetyo. "Industri 4.0: Telaah Klasifikasi Aspek Dan Arah Perkembangan Riset." Teknik Industri, Vol.13, No.1, 2018, 22-27. Diakses 17 Mei $2020 . \quad \mathrm{http} / / \mathrm{dx}$. doi.org/10. 12962/j23546026.y2018i5.4417.
Sangaji, Niko. "Pengaruh Revolusi Industri 4.0 Pada Kewirausahaan Untuk Kemandirian Ekonomi." Seminar Nasional \& Call For Paper Seminar Bisnis Magister Manajemen, 2019, 226-32. Diakses 19 Mei 2019. http://hdl.handle.net/11617/11088.

Tobeli Evi. "Pemahaman Remaja Kristen Dalam Menghadapi Perkembangan Ilmu Pengetahuan dan Teknologi (IPTEK)." Penabiblos, Vol.6, No.1 (2017), 76-77. Diakses 20 Mei 2020.

Tafonao, Talizaro. 'Peran Pendidikan Agama Kristen Dalam Keluarga Terhadap Perilaku Ana', Edudikara: Pendidikan dan Pembelajaran Vol.3, No.2, (2018), 126. Diakses 20 Mei 2020. Doi: 10.5281/zenodo.2783994.

Wadi, Elsyana Nelce, and Elisabet Selfina. "Peran Orang Tua Sebagai Keluarga Cyber Smart Dalam Mengajarkan Pendidikan Kristen Pada Remaja GKII Ebenhaezer Sentani Jayapura Papua." Jaffray, Vol.14, No.1, (2016), 80. Diakses $20 \quad$ Mei 2020. https://doi.org/10.25278/jj71.v14i1. 190 . 